\title{
THE EFFECT OF BENEFITS LEVEL ON TAKE-UP RATES: \\ EVIDENCE FROM A NATURAL EXPERIMENT
}

\author{
MOMI DAHAN \\ UDI NISAN
}

CESIFO WORKING PAPER NO. 1885

CATEGORY 1: PUBlic FinANCE

JANUARY 2007

An electronic version of the paper may be downloaded

- from the SSRN website:

- from the RePEc website:

www.SSRN.com

- from the CESifo website: 


\title{
THE EFFECT OF BENEFITS LEVEL ON TAKE-UP RATES: EVIDENCE FROM A NATURAL EXPERIMENT
}

\begin{abstract}
This paper exploits a quasi-natural experiment to study the effect of social benefits level on take-up rates. We find that households who are eligible for double benefits (twins) have much higher take-up rate - up to double - as compared to a control group of households. Our estimated effect of benefits level is much higher relative to the standard cross section estimates. This finding is less exposed to a selection bias that might plague much of the previous research on the link between benefits level and take-up. It provides strong empirical support for the level of benefits as a key factor in determining take-up rates.
\end{abstract}

JEL Code: I38.

Keywords: take-up, social benefits.

\author{
Momi Dahan \\ School of Public Policy \\ Hebrew University Jerusalem \\ Mount Scopus \\ Jerusalem 91905 \\ Israel \\ MomiDahan@mscc.huji.ac.il
}

\author{
Udi Nisan \\ School of Public Policy \\ Hebrew University Jerusalem \\ Mount Scopus \\ Jerusalem 91905 \\ Israel \\ UdiNisan@mscc.huji.ac.il
}

November 2006

Our thanks to Noam Zusman and the seminar participants of the School of Public Policy at the Hebrew University of Jerusalem. We also thank Tal Otiker and Liza Teper for their research assistance. This paper has been written while Momi Dahan was visiting the Center for Economic Studies (CES) in Munich. Momi Dahan would like to thank the CES for providing an ideal environment for research and for its very kind hospitality. We thank the Falk Institute for the financial support. We thank Gal Hershkovitz and "Hagihon" for providing us with the data. 


\section{Introduction}

Not all the poor who are eligible for welfare benefits do actually collect them. Low take-up rates of social benefits should be a concern for policy makers because it reduces the chances of achieving the policy goal. There is no consensus built regarding the three competing explanations for low take-up rates: administrative, stigma and information costs. In contrast, the strong positive effect of benefits level on take-up rates is one of the most solid findings in the literature on means-tested programs. ${ }^{4}$ This empirical relation found across social programs and across countries.

Yet, this finding might suffer the risk of a selection bias that even its direction is a priory unclear. This is because participation costs are likely to be indirectly related to the level of benefits in means-tested programs. For example, households who are eligible for lower benefits because of higher earnings skills may face a lower information cost in case these skills are also an important input in collecting and processing information. As a result, these skills that may not be observable are responsible for both lower benefits and lower participation costs.

The selection bias may also work in the opposite direction due to the potential negative relations between participation costs and social benefits level through other channels. For example, those who are better educated but still eligible for small benefits may face a high stigma cost. Again, the level of benefits and participation cost are jointly determined by a third variable which may not be observable. ${ }^{5}$

The goal of this paper is to study the effect of benefits level on take-up rates of social benefits as embodied in water consumption bills in the City of Jerusalem (Israel)

\footnotetext{
${ }^{4}$ This finding repeats itself in many works. For example, Blank and Card (1991) found that higher benefit replacement rates are correlated with higher take-up rates. Also, Ashenfelter (1983), Blank and Ruggles (1996), Anderson and Meyer (1997), McGarry (1996), Daponte et al (1999) and Bitler et al (2003) all share that positive correlation. For a more comprehensive survey of this literature see Currie (2004) and Hernanz et al. (2004).

${ }^{5}$ A selection bias may arise also because those who are eligible for small amount of benefits might be different from those who are entitled to large benefits. For instance, those who barely meet the program criteria and as result eligible for small benefits are likely to have higher income or wealth as compared to those who are eligible for large benefits. Differences in benefits level imply also differences in marginal utility that may affect the decision to collect social benefits. This selection problem may introduce estimation bias even after controlling for households characteristics to the extent that program criteria differ from those characteristics that are observable to econometricians.
} 
using a quasi-natural experiment strategy. The unique disaggregated data set on water consumers we have allows us to accurately define take-up. Take-up rate in the general population of Jerusalem is around 65 percent which is well within the range found in welfare programs in OECD countries (Hernanz et al, 2004).

To estimate that effect we use an exogenous event, a birth of twins to a four-member household which is uncontaminated by the influence of heterogeneity in participation costs. In our context the occurrence of a twins-birth is likely to be exogenous because better access to assisted reproductive technologies is not relevant as much as it is for the first or second birth. ${ }^{6}$

The water pricing structure in Israel consists of three increasing blocks tariffs (IBT). This pricing structure has an additional feature. Households larger than four persons are entitled to an additional 36 cubic meters per person per year at a low rate. The monetary value of that additional quantity of water could be up to 13 percent of annual water expenditures. This social benefit is non-automatic and a household must complete a very simple form (half a page) to take-up that social benefit. Every household, regardless of its income or wealth, is entitled to this social benefit.

We study the take-up patterns of two groups of households following a household expansion. The first group consists of four-member households that had expanded by one member (singleton). The second group is composed of households of four members that expanded to six members (twins). For robustness check we also followed the behavioral response of households who had twins but were three members before the household expansion.

We test whether households who had twins reacts differently in terms of taking-up their social benefits as compared to households who had singleton. The first group is entitled to double benefits according to the rules of the program while facing the same (direct) administrative and stigma costs. Due to the universality of the benefit, it is plausible to assume, that the stigma cost does not play an important role in our context.

\footnotetext{
${ }^{6}$ Note that a family of two adults and three children is very common in Israel (total fertility rate in Israel is close to three).
} 
A standard cost-benefits model suggests that eligible households would apply if the expected benefits are higher than the cost. The straightforward implication is that for a given cost of participation a positive relation exists between the level of benefits and take-up rates of social benefits. The exogenous event we employ here assures that participation costs do not vary with benefits level.

Twins-based studies add a valuable contribution to social sciences by providing us with better understanding of the causal relationship between various important variables such as earnings and schoolings (Ashenfelter and Kruger, 1994), the effect of fertility on labor supply (Rosenzweig and Wolpin, 1980b) and the link between quality and quantity of children (Rosenzweig and Wolpin, 1980a). Our paper is the first to use a twins event to study take-up rates of social benefits.

In the next section we describe the structure of social benefits in water consumption and the benefit calculation. In Section 2 a simple model of take-up is presented to guide our discussion regarding the potential risk of selection bias. Section 3 describes the definition of take-up and Section 4 presents the data. Section 5 presents the estimation methodology, results and robustness analysis and section 6 concludes.

\section{A simple model of take-up}

In this Section we sketch a very simple model to guide our discussion on the potential selection bias in estimating the effect of benefits level on take-up of social benefits. This model also provides us with theoretical prediction regarding that relation under various assumptions.

Suppose a household drives utility from monetary income only:

(1) $\mathrm{U}_{1}=\mathrm{U}(\mathrm{Y})$

where $U_{1}$ is the utility level in absence of welfare benefits, $\mathrm{Y}$ is income from all sources (wage and non-wage income) and $U$ follows the standard assumptions 
(monotonic and quasi-concave). If a household participates in a welfare program then the utility, $\mathrm{U}_{2}$ is:

(2) $\mathrm{U}_{2}=\mathrm{U}(\mathrm{Y}+\mathrm{B}-\phi)$

where B represents the level of welfare benefits and $\phi$ stands for participation costs. ${ }^{7}$ This formulation assumes that the costs of collecting welfare benefits are monetary costs only. Later we refer to the case of a non-monetary cost such as stigma that may affect utility differently. The level of benefits is determined by a commonly used equation (a formula that is used in many welfare programs throughout the world):

(3) $\mathrm{B}=\mathrm{G}-\mathrm{twH}-\mathrm{rN}$,

where $\mathrm{G}$ is a the level of benefits in case of zero income, $\mathrm{w}$ is the wage rate, $\mathrm{H}$ is the number of hours of work, $\mathrm{N}$ is non-wage income and $\mathrm{r}$ is the tax on non-wage income. $\mathrm{G}, \mathrm{t}$ and $\mathrm{r}$ are the same for all households but $\mathrm{w}, \mathrm{H}$ and $\mathrm{N}$ may vary across households. To keep the discussion simple, all six variables (G, t, r, w, H and N) are assumed to be exogenous but may affect the cost of participation in a particular way. It is more plausible to assume that $\mathrm{H}$ is an endogenous variable. Assuming that would reinforce the selection bias problem. According to Equation (3), the level of benefits is related to total income which is a key feature of means-tested programs.

Suppose that the costs of participation in a welfare program have both a fixed component and a variable component that varies with benefits level:

(4) $\phi=\phi_{0}+\phi_{1}(\mathrm{~B})$

A household will decide to participate in the program as long as benefits are greater than costs regardless of the level of income. That result is particular to the way the costs affect utility. A household is likely to participate the greater the benefits level is

\footnotetext{
${ }^{7}$ This formulation of $U_{2}$ is similar to the fixed stigma costs case in Moffitt (1983) but here we allow for both fixed and variable stigma costs. Unlike Moffitt (1983), our framework shows that the key assumption regarding the connection between benefits level and take-up rates is the way participation costs affects utility. That link is not sensitive to whether the participation cost is fixed or not.
} 
in case where $\phi_{0}>0$ and $\phi_{1}=0$, which is the most simple case. Obviously, a household would not participate regardless of benefits level if $\phi_{0}$ is high enough (more than $G$ ) or if $G$ is low enough. Thus, a positive correlation between take-up rates and benefits level is consistent with $\phi_{0}<\mathrm{G}$.

The results are qualitatively the same also in the more general case where participation costs varies with the level of benefits in additional to a fixed cost component. A household is expected to apply for benefits the higher the level of benefits is. This result is not sensitive to whether the participation costs are positively or negatively related to the level of benefits. Clearly, the participation in the program is worthwhile even at lower levels of benefits if the participation cost is negatively related to benefits level (as compared to the case of positive relation between benefits level and a participation cost).

This simple framework shows that positive relations between take-up and benefits level could be consistent with any type of participation costs (administrative, information or stigma) as long as this cost is low enough. Therefore the empirical finding mentioned above could not be used as supporting evidence for either the importance of administration, information or stigma costs.

Let us focus now on the relation between benefits level and participation costs. Suppose that those who have higher value of time (high $w$ ) are also better in collecting and processing information. It implies that those who have lower levels of benefits (high $w$ implies lower B given Equation (3)) are also likely to face lower participation costs. This has a direct econometric implication: estimating the effect of benefits level is biased unless the heterogeneity in costs is controlled for.

This is a suitable framework when administrative and information costs are the main costs of participation. These two types of costs are likely to have monetary implication both directly and indirectly through the value of time spent on applying, searching and processing information. However, if the main participation costs are associated with stigma then it makes more sense to model the decision to take up 
social benefits in a slightly different way. Rewrite Equation (2) with a minor but important change:

(5) $\mathrm{U}_{2}=\mathrm{U}(\mathrm{Y}+\mathrm{B})-\phi$,

Assume that all other equations are the same. A household decide to participate if $U_{2}$ $\mathrm{U}_{1}>\phi .{ }^{8}$ Under this structure, take-up rates are again related positively to the level of benefits assuming a fixed stigma cost. But here the decision to participate depends on the level of income given the assumed shape of utility function. For a given level of benefits and costs, those who have higher income are less likely to apply for welfare benefits. ${ }^{9}$ Thus, unlike the previous setting one has to control also for income differences to get unbiased effect of benefits level.

Suppose that those who have higher income also have higher stigma costs involved in collecting welfare benefit. ${ }^{10}$ In this case the cost of participation is related positively to the level of benefits because those who have higher income are entitled to lower benefits. This framework also predicts a positive connection between take-up rates and benefits level as long as $\phi_{1}(\mathrm{~B})$ is strictly concave. In contrast, the effect of benefits level on take-up is non-linear if $\phi_{1}(\mathrm{~B})$ is not strictly concave. For example if $\phi_{1}(\mathrm{~B})$ is linear in B then those who are eligible for both low and high B would not apply for welfare benefits while those who are entitled to intermediate levels of benefits would decide to take up their benefits.

This section shows that a selection bias is likely to be a problem in estimating the effect of benefits level on take-up rates because of unobservable heterogeneity in participation costs. The direction of the bias depends on the underlining assumptions regarding the relationship between income, participation costs and benefits level.

\footnotetext{
${ }^{8}$ This formulation of $U_{2}$ is similar to the fixed stigma costs case in Moffitt (1983) but again our is flexible to allow for both fixed and variable stigma costs. We show here that the type of relations between participation cost and benefits level (rather than fixed or variable) has an important implication for the predicted link between benefits level and take-up.

9 Household may differ in their income but still have the same level of benefits because different tax rates on different sources of income.

${ }^{10}$ Several studies show that take-up rates are negatively correlated with schooling and that finding might reflect higher stigma cost for better educated (and high Y) people.
} 
As it will be evident clearly later our estimator is less exposed to this type of bias. Our experiment is similar to a rise in $G$ which is less likely to interact with the cost of participation.

\section{Social benefit in water consumption}

The social benefit that is the focus of this paper is provided to all households in Israel in terms of reduced price for one of the most basic goods - water. In this regard it is close to in-kind transfer and is similar in nature to food stamps. The pricing structure of water in Israel consists of three increasing block tariffs (IBT). ${ }^{11}$

In 2002, the price in the first block, applying to the first 96 cubic meters (hereinafter: $\mathrm{m}^{3}$ ), was $\$ 1.2 / \mathrm{m}^{3}$ including a sewage surcharge. The price in the second block, for additional consumption up to 84 cubic meters, was $\$ 1.5 / \mathrm{m}^{3}$. The charge for all extra consumption was $\$ 1.9 / \mathrm{m}^{3}$.

This pricing structure has an additional feature. Households larger than four persons are entitled to an additional $36 \mathrm{~m}^{3}$ per year at a low rate for each member above four. ${ }^{12}$ This particular feature has been an integral part of IBT structure for more than 30 years, and is both universal and non-automatic. To receive this social benefit a household must report on household size: half a page requesting only the names and ID numbers of all household members.

A household must report to the water utility provider every time a new member joins the household in order to get the supplementary quantity of water at a low price. This benefit may continue for years until a member leaves the household. According to the law, the benefit starts on the reporting date onward (no retroactive incidence). The social benefit takes effect right after reporting (i.e., the next billing period). There is no uncertainty regarding the outcome of the application process and in practice no rejections occurs.

\footnotetext{
${ }^{11}$ Israel was one of the pioneers in using IBT Pricing structure. In the past twenty years it has seen a global trend toward the use of IBT (OECD 1999).

${ }_{12}$ Households with irrigated lawns are allowed an additional $0.6 \mathrm{~m}^{3}$ per square meter per year, up to $300 \mathrm{~m}^{3}$, at a low price (excluding sewage surcharge).
} 


\subsection{Benefit calculation}

We define social benefit in this paper as the difference between the current (virtual) water bill in the case of reporting on household size and virtual (current) water bill in the case of non-reporting. Unlike food stamps, the social benefit here depends on the level of (water) consumption. For example, the social benefit could even be zero if water consumption is low enough (Equation 1).

As can be seen in Equation (1), the calculated benefit depends non-linearly on the level of water consumption. This equation applies for a household larger than four persons without a lawn.

$$
S B=\left\{\begin{array}{lc}
0 & \text { if } C \leq 96 \\
(C-96)\left(P_{2}-P_{1}\right) & \text { if } 96<C \leq 180 \text { and } X \leq 96 \\
36 N\left(P_{2}-P_{1}\right) & \text { if } 96<C \leq 180 \text { and } X>96 \\
84\left(P_{2}-P_{1}\right)+(C-180)\left(P_{3}-P_{1}\right) & \text { if } C>180 \text { and } X \leq 96 \\
(180-X)\left(P_{2}-P_{1}\right)+(C-180)\left(P_{3}-P_{1}\right) & \text { if } C>180 \text { and } 96<X \leq 180 \\
36 N\left(P_{3}-P_{1}\right) & \text { if } C>180 \text { and } X>180
\end{array}\right\}
$$

Where SB denotes the yearly social benefit, C denotes the actual water consumption, $\mathrm{N}$ denotes the true number of persons above four and $\mathrm{P}_{\mathrm{i}}$ denotes the marginal price of water at block i. $\mathrm{X}$ is defined as the difference between the actual water consumption and 36 multiply by $\mathrm{N}$. Recall that every household is entitled to $96 \mathrm{~m}^{3}$ of water at a low rate and an additional $84 \mathrm{~m}^{3}$ at an intermediate rate.

The maximum yearly social benefit for an additional household member equals the difference between the highest and lowest price multiplied by the supplementary quantity (Figure 1). The maximum present value of social benefit per person is approximately \$315. For a given price, the level of benefits is exactly double for a household of four who expanded by two (twins). To obtain the maximum present value of social benefits for a household, that amount should be multiplied by the number of household members above four for each year. 
Figure 1: Yearly social benefit for the fifth and sixth members

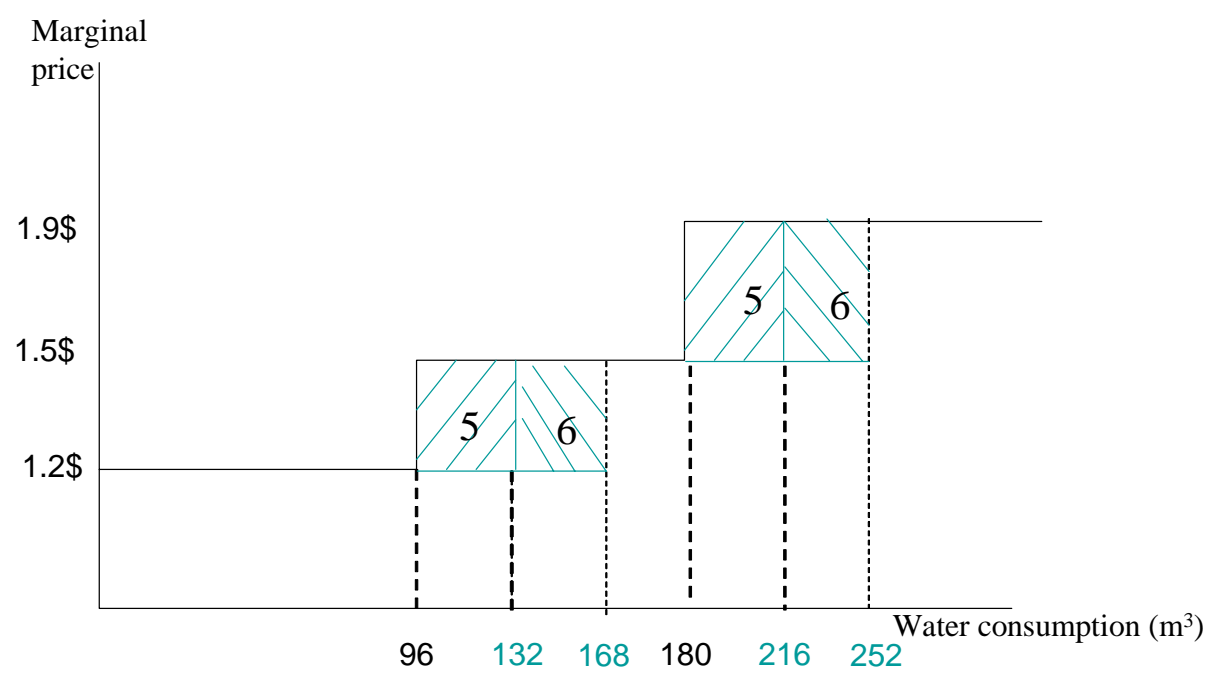

\section{The definition of take-up}

There are two alternative ways to define take-up in this paper. One way is to define take-up based on the reporting status of households. An alternative definition of takeup could be based on the presence of a positive social benefit in addition to reporting status. We employ only the first definition for reasons that are discussed below.

According to the first definition, the eligible population is divided into participants and non-participants. Participants are those households that have reported to "Hagihon" the same number of individuals as appears in the official files in the Ministry of the Interior. We assume here that the size of a household in the official files is also the actual size. These data files are used by the Israeli government for many purposes such as determining child allowance eligibility, elections, and drafting the relevant population into the army. Our database does not contain the household age structure and reporting date. Therefore, we do not know the length of participation.

The definition of take-up that we use, which is based on the household's reporting status, may include households that have ex-post zero social benefit due to a low level 
of water consumption in the current year and seemingly has no incentive to report. The weakness of using the first definition is quantitatively limited. Most households in our working data set are not in the lowest price category. Most of five-member households is either at the intermediate or highest marginal price level (Table 3).

Alternatively, we could have defined take-up in the following way: a reporting household that is also entitled to a positive social benefit is defined as a participant. Those households that are entitled to a positive social benefit and yet do not report would have been defined as non-participants.

However, a rational household should decide to report based on the expected present value of social benefits that could be different from the ex-post calculation of social benefit in the current year. Recall that the calculated social benefit depends on actual water consumption, which is uncertain. The alternative definition would overlook households who had positive benefits in the past (and may have in the future) but have zero benefits at the current year.

A definition that is based on the calculated social benefit may be exposed to an endogeneity problem. The dependent variable in this case - entitlement to a positive social benefit - is influenced by the household level of water consumption. Actual water consumption is clearly an endogenous variable and is associated with household characteristics. For example, poor households tend to have disproportional zero social benefits because of low level of water consumption while rich households more likely to have a positive social benefit due to their high consumption level. Therefore, using take-up as a dependent variable based on this definition would introduce an endogeneity problem when household wealth indicators are used as explanatory variables.

The alternative definition may be exposed to an additional source of endogeneity. The endogeneity results from the negative relationship between reporting status and water price. Those households who do not report on their size face higher price compared to households who do report, holding everything else constant. The actual level of water consumption of households who do report may be higher. The calculated benefits for reporting households are biased to the extent that the elasticity of water consumption 
is negative (Dahan and Nisan, 2007). Thus, it generates a spurious positive correlation between the level of social benefits and the likelihood of reporting.

\section{Data}

The original data set we have covers all households in Jerusalem for the years 19992002. ${ }^{13}$ Our data set comes from three main sources: "Hagihon," the only water utility in Jerusalem; the Municipality of Jerusalem; and the Israel Ministry of the Interior. Most of the data originate with the Municipality of Jerusalem and were merged with household water consumption data from "Hagihon" and household size at the end of each year from the Ministry of the Interior.

In the merged data set we have information on household size from two different sources: household size as reported to "Hagihon" and household size as documented in the Ministry of the Interior. This allows us to identify those households that are entitled to the social benefit but do not collect it. Thus, the use of these two data sources enables us to define eligibility and take-up in a relatively precise way.

As discussed previously, the eligible population is composed of households larger than four persons. The main focus is to analyze take-up rate patterns following a family expansion of those households that are four persons or larger. As a result, all households of four persons or less were excluded.

Our main working population consists of households that had expanded between 1999 and 2002 according to the official files (i.e., the Ministry of Interior). We constructed three different pools (A, B and C) that differ in time distance between household expansion and the timing we examine the reporting status.

The first pool is composed of three panels - 1999-2000, 2000-2001 and 2001-2002 where in the first pool we have information on the same household for two

\footnotetext{
${ }^{13}$ We excluded observations for several reasons (commercial consumers, shared meters consumers, households larger than twelve individuals, households metered during part of the year and identification mismatch at different sources).
} 
consecutive years. ${ }^{14}$ This allows us to identify those households that had expanded during the second year and their reporting status at the end of the same year, a half year after the expansion on average. For the sake of conciseness, throughout the paper we use one year, two years and three years instead of a half year, a year and a half and two years and half, respectively.

The second pool includes two panels - 1999-2001 and 2000-2002. We follow the same household for three consecutive years. This covers those households that had expanded during the second year together with their reporting status at the end of the third year, a year and half after the expansion on average. The third pool, which is in fact a panel, is composed of households with information for four consecutive years (1999-2002). This covers those households that had expanded during the second year together with their reporting status at the end of the fourth year, two years and half after the expansion on average. In both pools B and C those households that were expanded more than once were excluded because those households face a different administrative cost and are entitled to double or even triple social benefits.

In all three pools, we focus on three groups of households. The first group of households is those who were four and expanded by two. In pool A the first group (hereinafter: the treated group) is composed of 79 households (Table 1). The second group of pool A consists of 2,656 four-member households that expanded by one member only. These households are our main control group. We also use households that expanded by two but were three members before the expansion as an additional treated group. In pool A this third group covers 97 households.

Table 2 presents take-up rates using the definition outlined above for various time lags between the date of expansion and timing of reporting status. The take-up rate among households of four members that become five is around 41 percent two years after the expansion. This is much lower compared to the take-up rate among households of four members that become six which is 66 percent. ${ }^{15}$ The gap in take-

\footnotetext{
${ }^{14}$ The data available to us consists of households who stay in the same apartment for the entire period in each panel.

${ }^{15}$ This average masks a huge difference between the two panels included in pool B. The take up rate in the first panel (1999-2001) is 82 percent while it is only 50 percent in the second panel (2000-2002). We do not have a good explanation for that drop in take-up rate.
} 
up rates between the treated and control group is even higher in the third panel (19992002), 44 percentage points. Note that the take-up rates of household who expanded to five but were three members before the expansion is just slightly higher than that of household who expanded to five but were four members before the expansion.

Time distance between the date of expansion and reporting status matters as is evident in Table 2. The take-up rate after two years is almost twice as much as the rate after one year (which is in fact six months on average). Clearly, it takes some time to collect the social benefit associated with reporting. The take-up after three years is just slightly higher compared to two years. For example, the take-up rate among households of four members that become five 20 percent after one year, 41 percent after two years and 45 percent three years after the expansion. Notice that these takeup rates are different from the take-up rates of the same household for various time distances. A similar picture arises following take-up rates patterns of the same households over four years period (Table 4).

\section{Estimation}

\subsection{Methodology}

In order to examine the effect of social benefits level on take-up we distinguish between two separate groups of households. These two groups are identical in the following sense: they both expanded at the beginning of the respective period. The first type is a four-member household that expanded by one member and therefore is entitled to an additional $36 \mathrm{~m}^{3}$ of water at a low rate. The second type is a fourmember household that expanded by two members (twins) at the beginning of the respective period. Those households are eligible for an additional $72 \mathrm{~m}^{3}$ of water at a low rate according to the rules of the program.

For a given price, the treated group is entitled to double benefits compared to the control group but face the same direct administrative cost. The social benefit in water consumption is associated with a low administrative cost. To obtain the supplementary quantity of water at a low price, a household must fill out a very 
simple form: half a page requesting only the names and ID numbers of all household members, and the attached birth certificate of the newborn (see Appendix 1). A household may declare on one, two or even more additional members on the same form. In Israel, every family automatically receives a birth certificate immediately after a baby is born. The form may be sent by regular mail (cost of a stamp) or via fax (cost of a phone call).

Reporting the number of household members does not require sharing information regarding the household's economic conditions such as income, wealth or working status with the water utility officials, information that may be associated with psychological or social costs as in the case of income maintenance programs. This additional quantity is given to every household above four regardless of its income. Thus, both the treated and control groups face the same negligible stigma cost due to the universality of that social benefit.

Potentially, the treatment effect (higher social benefits) may be influenced by differences in household characteristics. In general, the twins-event may not be exogenous and might be related to household characteristics. For example, families with high income may have better access to infertility treatment and therefore may be characterized by a higher probability of having twins. This might be true for the first birth while here the twins-event is conditional on that the household has already four members.

Table 5a presents household characteristics for both groups. It shows that in general the treated and control groups share similar characteristics and that should affect our confidence regarding the random assignment of these two groups. The differences in characteristics are not statistically significant except for one case (out of three) where the share of Orthodox Jews households who had a twins-birth is significantly higher. Therefore, there is less risk of systematic differences in participation costs between the treated and control groups due to differences in household characteristics.

For a robustness test we use households of three members that had expanded by two (twins) as an alternative control group. This group of households is entitled to the same benefits level as a household of four members who expanded by one member 
and also face the same administrative cost. By using an alternative control group we are able to examine whether the twins event in itself (not related to benefits level) plays a role in shaping take-up rates.

As expected, when comparing between households of three and four members there are more cases of significant differences (Table 5b). This reflects the fact that household size before the expansion in one group is lower and it may be correlated with other household characteristics. For example, the share of Orthodox Jews households who had a twins birth is significantly higher among four-member households, and it reflects the tendency of this population group to have more children. Yet, there are more cases where the differences are not significant. In particular, in two cases (out of three) there is no significant difference between these two groups in apartment size which is a key wealth indicator.

\subsection{The estimated models}

We estimate two alternative models: the first model does not control for any household characteristics while the other model addresses a potential effect of the differences in household characteristics and a year effect.

First model:

(2) $\mathrm{y}_{\mathrm{i}}=\mathrm{a}+\mathrm{bD}_{\mathrm{i}}+\varepsilon_{\mathrm{i}}$,

and second model:

(3) $\mathrm{y}_{\mathrm{i}}=\alpha+\beta \mathbf{x}_{\mathrm{i}}+\gamma \mathrm{D}_{\mathrm{i}}+\delta_{\mathrm{j}} \mathrm{t}_{\mathrm{j}}+\varepsilon_{\mathrm{i}}$,

where, $\mathrm{y}_{\mathrm{i}}$ is a dummy variable that is equal to one for a household that had reported and zero otherwise. $\mathbf{x}_{\mathrm{i}}$ denotes a vector of household characteristics in the respective period and $D_{i}$ represents a dummy variable for the treatment effect. $D_{i}$ is a binary variable that equals 1 for a treated household and zero for a control household. We also control for a year effect, $\mathrm{t}_{\mathrm{j}}$ where there are two separate year effects in the case of three panels, one year effect in the case of two panels and no year effect in the case of three years panel. 
The vector $\mathbf{x}$ includes an array of household characteristics, as documented before the expansion, that may affect reporting behavior. There are three types of variables: wealth indicators (apartment size, garden size and poverty indicator ${ }^{16}$ ), social network indicators (Orthodox Jews and Arabs), language barrier (Arabs) and the virtual marginal price of water faced by a household which represents an additional dimension of the level of social benefits.

The net effect of wealth on take-up is uncertain. A simple cost-benefit model of collecting social benefits would predict that take-up rates should be falling as wealth rises due to lower marginal utility. This is true under certain formulation as shown in Section 2. But on the other hand, wealth may affect take-up rates indirectly (through the connection between education and wealth) because we do not control for education in our regressions. A wealthier household may incur a lower cost of collecting and processing information given the positive relations between wealth and education.

According to the recent literature, we hypothesize that a household that belongs to a social network is more likely to be informed and as a result would have higher probability of reporting (Bertrand et al, 2000). ${ }^{17}$ In Jerusalem there are two large distinct ethnic groups that may be classified as social networks: Orthodox Jews and Arabs. An Orthodox Jewish household is defined as such if it is located in an Orthodox neighborhood as classified in the Jerusalem master plan. Similarly, a household is defined as Arab if it lives in an Arab neighborhood as classified in the Jerusalem master plan. Each one of these two groups maintains close personal relations internally and has little social connection with the rest of the population. In fact, the Arab population has almost no social connection with the Jewish population.

In addition, an Arab household may face a language barrier. Although the criteria for an additional quantity of water at a low rate are outlined both in Hebrew and Arabic on the back page of every water bill, the application form is available in Hebrew only. Part of the Arabs population in East Jerusalem who affiliate themselves with the

\footnotetext{
${ }^{16}$ In this paper, a household is considered below the poverty line if it is entitled to a municipal tax deduction. This tax deduction is means-tested and is indirectly related to the formal poverty line in Israel.

${ }^{17}$ See also Duflo and Saez 2003, Borjas and Hilton 1996.
} 
Palestinian Authority tend to minimize the frequency of contacts with Israeli official authorities. Therefore, they may be less exposed to information regarding their entitlement to social benefits. The Arab population may face lower information costs due to the social network but at the same time incurs higher information costs due to language barrier. Thus, the net effect must be examined empirically.

As noted before, the treated group is entitled to a double quantity of water at a low rate following the current expansion by two members. Those households who gave birth to twins at the beginning of the period are expected to have higher take-up rates compared to the control group for a given application cost.

Note that the actual level of social benefits may differ also depending on the actual level of water consumption that determines the marginal price paid by a household. We control for the virtual marginal price which is a proxy to that dimension of benefits level. A marginal virtual price is defined as the marginal price that would have been faced by a household given its actual water consumption in the event of no reporting on household size.

In general, households that reported on the current expansion face a lower (actual) marginal price as compared to households that did not report. This may affect their actual water consumption to the extent that price elasticity of water demand is negative. The virtual price might be higher for a reporting household and as a result the coefficient might be biased downward.

\subsection{Results}

We run an OLS regression with and without control variables for household characteristics. The outcomes of interest in our case are limited dependent variables. However, as noted in Angrist (2001), the problem of causal inference for these variables is not fundamentally different from continuous outcomes. If there are no covariates or the covariates are sparse and discrete, linear models are no less appropriate than other types of dependent variables. The OLS coefficients of dummy variables have a natural interpretation as the average change in take-up rates. ${ }^{18}$

\footnotetext{
${ }^{18}$ Table 7 presents Logit regressions and the general picture is the same.
} 
To estimate the effect of benefits level as captured by our treatment dummy variable we use three different pools, according to the time gap between the year of household expansion and the date of reporting on that expansion. In the first pool the dependent variable is defined based on the reporting status of a household a year after the expansion. The second and third pools are based on reporting status two and three years after the household expansion, respectively.

Table 6 reports the coefficients and t statistics for the two estimated models. In a regression without any control variable, the take-up rates of those households of four members who expanded by twins are higher but the significance is borderline when take-up is examined at the end of expansion year. However, the coefficient of the treated group is around 25 percentage points higher and very significant when the reporting status is detected at the end of the second year after the expansion (in a regression without any control variable). The magnitude of the treatment effect is even much higher when the reporting status is checked at the end of the third year since the household expansion.

As can be seen from Table 6, the dummy variable for households who had twins but were three members before that household expansion is not significantly different from zero in all cases. It implies that their behavioral response is similar to those households of four-members who had expanded to five.

These two groups of households are entitled to the same benefits level and a direct administrative cost and they indeed react in similar way. This finding suggest that the driving force behind our main result regarding the positive connection between benefits level and take-up rates are not related to the twins event in itself but rather to the real differences in benefits level across households.

We saw earlier that in some cases the treated and control groups are not completely identical in all their characteristics. In the second estimated model we control for both household characteristics and a year effect. The year effect turns out to be insignificant in all cases. The results appear in Table 6 show that the effect of treatment is only slightly lower, after controlling for various explanatory variables and 
a year effect. The magnitude of the treatment effect is closer to the first estimated model regardless of when the reporting status is examined.

The coefficients estimated in both models imply a quantitatively very large effect. The estimated take-up rate of the treated group is at least 42 percent higher as compared to the control group. This supports the idea that benefits level play a key role in shaping take-up rates.

As discussed above, the Arab household dummy variable reflects two conflicting forces in terms of information costs. The negative sign of this coefficient and its magnitude is consistent with the hypothesis that language barrier has much more influence than social network. The Arab coefficient implies close to 20 percentage points lower take-up rate for an Arab household when reporting status is detected at the end of the third or fourth year since household expansion.

The Orthodox Jewish dummy variable represents a lower information cost due to better social network. As expected, the coefficient is positive and it is highly significant.

As anticipated, the level of social benefits positively affects take-up rates as implied by the virtual price coefficient. A lower virtual price implies also lower social benefit level that means less incentive (or no incentive) for a household to report on household size. In general, the coefficient of virtual price A (the price lowest) is significantly negative compared to the intermediate price. This result is in line with our main finding which attributes important role for benefits level in determining take-up rates.

In general, all wealth indicators (apartment size by quintiles, garden size and poverty indicator) are insignificant. This finding is consistent with either the theoretical framework presented in Section 2 where participation costs are monetary only or with the notion that lower marginal utility associated with higher wealth level is canceled out by the effect of lower information costs related to higher level of education and wealth. 
To get an order of magnitude of the selection bias that might be associated with simple cross-section regression, we run a similar specification to the one in Table 6 but where all households in our data set that consist of either five or six members. ${ }^{19}$ Those households who have six members are eligible for higher benefits level as compared to five-member households and are expected to have higher take-up rate. Seemingly, the difference in take-up rate should be the same as the gap between our treated and control groups.

Table 8 shows that the estimated effect of benefits level on take-up rate is much smaller in that cross-section regression as compared to our estimates based on quasinatural experiment. The coefficient of a six-member household is 4.6 percentage points whereas in the twins-event the estimate is almost 8 times higher when the reporting status is detected after three years. ${ }^{20}$ This exercise highlights the potential risk of a selection bias.

In our context, part of the selection bias comes from the positive relation between participation costs and benefits level embodied in the program. A household of six members is entitled to higher benefits but also face higher administrative costs because a household has to apply for benefits following each household expansion which is twice as much for a household of six members. Thus, the lower estimate of benefits level on take-up partially may reflect the burden of higher costs on household of six members.

\section{Conclusions}

This paper presents the estimated effect of benefits level on take-up patterns of social benefits. The quasi-natural experiment that we employ generates estimates that are much less exposed to a selection bias. In addition, the two reliable sources we have on

\footnotetext{
19 For example, Currie (2000) uses the family size as a proxy for benefits level in cross-section regression.

${ }^{20}$ A six-member household is defined in this exercise as a participant if and only if that household had reported on both the fifth and sixth members. According to this definition a six-member household is entitled to double benefits as compared to a five-member household.
} 
eligibility and take-up allow us to estimate the effect of benefits level based on a precise definition of take-up.

We show that households who are entitled to higher benefits have substantially higher take-up rate compared to a control group of households. Households who expanded by two members and as a result are eligible for double benefits have higher take-up rates as compared to a control group of households (households that expanded by one member).

The difference in terms of take-up rates is both highly significant and quantitative very large when the reporting status is checked at the end of the second or third year. The take-up rate of our treated group is twice of that of the control when the reporting status is detected at the end of the third year, two years and half after the expansion on average. Under that time table, households of four members who had twins have both double benefits and double take-up rate as compared to our control group.

In contrast, exploiting the cross section variation in household characteristics as done in previous research generates a much lower estimated effect of benefits level on takeup rates. It implies that the estimated effect of benefits level is subject to a quantitatively very large selection bias using the more standard estimation strategy.

We found also that variables that are directly associated with information costs such as social network indicators (Orthodox Jews and Arabs) and language barrier (Arabs) have significant influence on take-up rates. In contrast, we do not trace significant effect of wealth indicators such as apartment size on take-up rates.

The main conclusion to be drawn from this paper is that the benefits level plays a major role in the decision to participate in a program. This finding may be consistent with all three explanations put forward in the literature: information, administrative and stigma costs (although stigma costs should not have a significant effect in our context). A rational household should invest more time collecting information as benefits get higher. Also, for a given administrative cost a household is more likely to participate when benefits level is higher. 
In designing a means-tested program a policy maker should consider setting welfare benefits at even higher level than what is needed by the targeted population account for all types of participation costs. Otherwise, part of the targeted population would choose not to participate and take-up rate is expected to be low when participation costs are high enough. Determining the level of benefits in a targeted program becomes even more complicated to the extent that participation costs are heterogeneous across the needy households. 
Table 1: The data by type of household (number of households)

\begin{tabular}{|c|c|c|c|c|}
\hline & Total & 4 who turn 5 & 4 who turn 6 & 3 who turn 5 \\
\hline Pool A (1 year) & 2,832 & 2,656 & 79 & 97 \\
\hline $1999-2000$ & 908 & 853 & 25 & 30 \\
\hline $2000-2001$ & 955 & 893 & 28 & 34 \\
\hline $2001-2002$ & 969 & 910 & 26 & 33 \\
\hline Pool B (2 years) & 1,469 & 1,377 & 44 & 48 \\
\hline 1999-2001 & 723 & 678 & 22 & 23 \\
\hline $2000-2002$ & 746 & 699 & 22 & 25 \\
\hline $\begin{array}{l}\text { Pool C (3 years) } \\
(1999-2002)\end{array}$ & 457 & 421 & 18 & 18 \\
\hline
\end{tabular}


Table 2: Take-up rates for different time horizon

\begin{tabular}{|l|l|l|l|}
\hline \multirow{2}{*}{ Sample } & \multicolumn{3}{c|}{ Type of household } \\
\cline { 2 - 4 } & \multicolumn{1}{|c|}{4 who turn 5 } & \multicolumn{1}{c|}{ 4 who turn 6 } & 3 who turn 5 \\
\hline Pool A (1 year) & $\mathbf{0 . 2 0}$ & $\mathbf{0 . 2 9}$ & $\mathbf{0 . 2 3}$ \\
\hline $1999-2000$ & 0.21 & 0.32 & 0.27 \\
\hline $2000-2001$ & 0.22 & 0.21 & 0.21 \\
\hline $2001-2002$ & 0.18 & 0.35 & 0.21 \\
\hline & & & 0.49 \\
\hline Pool B (2 years) & $\mathbf{0 . 4 1}$ & $\mathbf{0 . 6 6}$ & 0.52 \\
\hline $1999-2001$ & 0.42 & 0.82 & \\
\hline 2000-2002 & 0.41 & 0.50 & $\mathbf{0 . 5 0}$ \\
\hline & & & \\
\hline Pool C (3 years) & $\mathbf{0 . 4 5}$ & $\mathbf{0 . 8 9}$ & \\
\hline$(1999-2002)$ & & & \\
\hline
\end{tabular}


Table 3: Households distribution by actual price as documented before the expansion

\begin{tabular}{|l|c|c|c|c|c|c|}
\hline \multirow{2}{*}{ Actual price } & \multicolumn{5}{|c|}{ Type of household } \\
\cline { 2 - 7 } & 4 who turn 5 & \multicolumn{2}{c|}{4 who turn 6 } & \multicolumn{2}{c|}{ 3 who turn 5 } \\
\hline Pool A (1 year) & $\mathbf{2 6 5 6}$ & $\mathbf{1 0 0 \%}$ & $\mathbf{7 9}$ & $\mathbf{1 0 0 \%}$ & $\mathbf{9 7}$ & $\mathbf{1 0 0 \%}$ \\
\hline Low & 92 & $3.5 \%$ & 1 & $1.3 \%$ & 7 & $7.2 \%$ \\
\hline Intermediate & 1033 & $38.9 \%$ & 24 & $30.4 \%$ & 48 & $49.5 \%$ \\
\hline High & 1531 & $57.6 \%$ & 54 & $68.4 \%$ & 42 & $43.3 \%$ \\
\hline Pool B (2 years) & $\mathbf{1 3 7 7}$ & $\mathbf{1 0 0} \%$ & $\mathbf{4 4}$ & $\mathbf{1 0 0 \%}$ & $\mathbf{4 8}$ & $\mathbf{1 0 0 \%}$ \\
\hline Low & 52 & $3.8 \%$ & 1 & $2.3 \%$ & 2 & $4.2 \%$ \\
\hline Intermediate & 482 & $35.0 \%$ & 14 & $31.8 \%$ & 24 & $50.0 \%$ \\
\hline High & 843 & $61.2 \%$ & 29 & $65.9 \%$ & 22 & $45.8 \%$ \\
\hline Pool C (3 years) & $\mathbf{4 2 1}$ & $\mathbf{1 0 0 \%}$ & $\mathbf{1 8}$ & $\mathbf{1 0 0 \%}$ & $\mathbf{1 8}$ & $\mathbf{1 0 0 \%}$ \\
\hline Low & 12 & $2.9 \%$ & 0 & $0.0 \%$ & 0 & $0.0 \%$ \\
\hline Intermediate & 120 & $28.5 \%$ & 6 & $33.3 \%$ & 10 & $55.6 \%$ \\
\hline High & 289 & $68.7 \%$ & 12 & $66.7 \%$ & 8 & $44.4 \%$ \\
\hline
\end{tabular}


Table 4: Take-up rates for different time distances for the same household

\begin{tabular}{|c|c|c|c|}
\hline $\begin{array}{c}\text { Time Length since } \\
\text { eligibility date }\end{array}$ & $\begin{array}{c}4 \text { that become 5 } \\
\text { (Control Group) }\end{array}$ & $\begin{array}{c}4 \text { that become 6 } \\
\text { (Treated Group) }\end{array}$ & $\begin{array}{c}3 \text { that become 5 } \\
\text { (Control group) }\end{array}$ \\
\hline One year & $16 \%$ & $28 \%$ & $28 \%$ \\
\hline Two years & $37 \%$ & $83 \%$ & $44 \%$ \\
\hline Three years & $45 \%$ & $89 \%$ & $50 \%$ \\
\hline No. of observations & $\mathbf{4 2 1}$ & $\mathbf{1 8}$ & $\mathbf{1 8}$ \\
\hline
\end{tabular}


Table 5a: Descriptive statistics - a comparison of treated and control groups

\begin{tabular}{|c|c|c|c|c|c|c|}
\hline & & & $\begin{array}{c}\text { Apartment } \\
\text { Size } \\
\text { (square } \\
\text { meter)* } \\
\end{array}$ & $\begin{array}{l}\text { Share of } \\
\text { Orthodox } \\
\text { Jews }\end{array}$ & $\begin{array}{l}\text { Share } \\
\text { of } \\
\text { Arabs }\end{array}$ & $\begin{array}{l}\text { Annual Water } \\
\text { Consumption } \\
\text { (cubic meter) * }\end{array}$ \\
\hline \multirow[t]{8}{*}{ One year } & \multirow{3}{*}{4 turn 6} & Obs & 60 & 79 & 79 & 79 \\
\hline & & Mean & 74.70 & 0.38 & 0.04 & 199.49 \\
\hline & & Std & 22.06 & 0.49 & 0.19 & 79.37 \\
\hline & \multirow[t]{3}{*}{4 turn 5} & Obs & 1,894 & 2,656 & 2,656 & 2,656 \\
\hline & & Mean & 73.23 & 0.36 & 0.06 & 181.96 \\
\hline & & Std & 21.95 & 0.48 & 0.23 & 91.87 \\
\hline & & $\begin{array}{l}\text { Means' } \\
\text { Difference }\end{array}$ & 1.47 & 0.02 & -0.02 & 17.53 \\
\hline & & T statistic & 0.51 & 0.28 & -0.84 & 1.93 \\
\hline \multirow{8}{*}{$\begin{array}{l}\text { Two } \\
\text { Years }\end{array}$} & \multirow[t]{3}{*}{4 turn 6} & Obs & 35 & 44 & 44 & 44 \\
\hline & & Mean & 75.97 & 0.43 & 0.05 & 193.00 \\
\hline & & Std & 21.17 & 0.5 & 0.21 & 76.11 \\
\hline & \multirow[t]{3}{*}{4 turn 5} & Obs & 1,083 & 1,377 & 1,377 & 1,377 \\
\hline & & Mean & 74.60 & 0.35 & 0.06 & 188.12 \\
\hline & & Std & 22.74 & 0.48 & 0.23 & 94.85 \\
\hline & & $\begin{array}{l}\text { Means' } \\
\text { Difference }\end{array}$ & 1.37 & 0.08 & -0.01 & 4.88 \\
\hline & & T statistic & 0.38 & 1.11 & -0.28 & 0.42 \\
\hline \multirow{8}{*}{$\begin{array}{l}\text { Three } \\
\text { Years }\end{array}$} & \multirow[t]{3}{*}{4 turn 6} & Obs & 17 & 18 & 18 & 18 \\
\hline & & Mean & 78.82 & 0.50 & 0 & 189.55 \\
\hline & & Std & 25.50 & 0.51 & 0 & 58.97 \\
\hline & \multirow[t]{3}{*}{4 turn 5} & Obs & 350 & 421 & 421 & 421 \\
\hline & & Mean & 77.14 & 0.21 & 0.08 & 199.47 \\
\hline & & Std & 23.84 & 0.41 & 0.27 & 97.44 \\
\hline & & $\begin{array}{l}\text { Means' } \\
\text { Difference }\end{array}$ & 1.68 & 0.29 & -0.08 & -9.91 \\
\hline & & T statistic & 0.27 & 2.9 & - & -0.67 \\
\hline
\end{tabular}

* before household expansion 
Table 5b: Descriptive statistics - a comparison of (alternative) treated and control groups

\begin{tabular}{|c|c|c|c|c|c|c|}
\hline & & & $\begin{array}{l}\text { Apartment } \\
\text { Size } \\
\text { (square } \\
\text { meter)* }\end{array}$ & $\begin{array}{c}\text { Share of } \\
\text { Orthodox } \\
\text { Jews }\end{array}$ & $\begin{array}{l}\text { Share } \\
\text { of } \\
\text { Arabs }\end{array}$ & $\begin{array}{l}\text { Annual Water } \\
\text { Consumption } \\
\text { (cubic meter) * }\end{array}$ \\
\hline \multirow[t]{8}{*}{ One year } & \multirow[t]{3}{*}{3 turn 5} & Obs & 67 & 97 & 97 & 97 \\
\hline & & Mean & 72.90 & 0.23 & 0.04 & 172.39 \\
\hline & & Std & 22.40 & 0.42 & 0.20 & 129.03 \\
\hline & \multirow[t]{3}{*}{4 turn 5} & Obs & 1,894 & 2,656 & 2,656 & 2,656 \\
\hline & & Mean & 73.23 & 0.36 & 0.06 & 181.96 \\
\hline & & Std & 21.95 & 0.48 & 0.23 & 91.87 \\
\hline & & $\begin{array}{l}\text { Means' } \\
\text { Difference }\end{array}$ & -0.34 & -0.13 & -0.02 & -9.57 \\
\hline & & T statistic & -0.12 & -2.97 & -0.73 & -0.72 \\
\hline \multirow{8}{*}{$\begin{array}{l}\text { Two } \\
\text { Years }\end{array}$} & \multirow[t]{3}{*}{3 turn 5} & Obs & 38 & 48 & 48 & 48 \\
\hline & & Mean & 69.87 & 0.21 & 0.06 & 187.53 \\
\hline & & Std & 16.23 & 0.41 & 0.24 & 160.40 \\
\hline & \multirow[t]{3}{*}{4 turn 5} & Obs & 1,083 & 1,377 & 1,377 & 1377 \\
\hline & & Mean & 74.60 & 0.35 & 0.06 & 188.12 \\
\hline & & Std & 22.74 & 0.48 & 0.23 & 94.85 \\
\hline & & $\begin{array}{l}\text { Means' } \\
\text { Difference }\end{array}$ & -4.73 & -0.14 & 0.01 & -0.59 \\
\hline & & T statistic & -1.74 & -2.35 & 0.20 & -0.03 \\
\hline \multirow{8}{*}{$\begin{array}{l}\text { Three } \\
\text { Years }\end{array}$} & \multirow[t]{3}{*}{3 turn 5} & Obs & 16 & 18 & 18 & 18 \\
\hline & & Mean & 65.25 & 0.27 & 0 & 225.93 \\
\hline & & Std & 14.98 & 0.46 & 0 & 242.07 \\
\hline & \multirow[t]{3}{*}{4 turn 5} & Obs & 350 & 421 & 421 & 421 \\
\hline & & Mean & 77.14 & 0.21 & 0.08 & 199.47 \\
\hline & & Std & 23.84 & 0.41 & 0.27 & 97.44 \\
\hline & & $\begin{array}{l}\text { Means' } \\
\text { Difference }\end{array}$ & -11.89 & 0.06 & -0.08 & 26.47 \\
\hline & & T statistic & -3.01 & 0.60 & -5.98 & 0.46 \\
\hline
\end{tabular}

*before household expansion 
Table 6: OLS estimates of benefits level effect on take-up rates

\begin{tabular}{|c|c|c|c|c|c|c|}
\hline \multirow[b]{2}{*}{ Intercept } & \multicolumn{2}{|c|}{ After One Year } & \multicolumn{2}{|c|}{ After Two Years } & \multicolumn{2}{|c|}{ After Three Years } \\
\hline & $\begin{array}{c}\mathbf{0 . 2 0} \\
(25.73) \\
\end{array}$ & $\begin{array}{c}\mathbf{0 . 1 6} \\
(4.53) \\
\end{array}$ & $\begin{array}{c}\mathbf{0 . 4 1} \\
(31.17) \\
\end{array}$ & $\begin{array}{c}\mathbf{0 . 3 3} \\
(5.95) \\
\end{array}$ & $\begin{array}{c}\mathbf{0 . 4 5} \\
(18.77) \\
\end{array}$ & $\begin{array}{c}\mathbf{0 . 3 9} \\
(4.18) \\
\end{array}$ \\
\hline Twins (4 turn 6) & $\begin{array}{c}0.09 \\
(1.95)\end{array}$ & $\begin{array}{c}0.07 \\
(1.61)\end{array}$ & $\begin{array}{c}\mathbf{0 . 2 5} \\
(3.25)\end{array}$ & $\begin{array}{c}\mathbf{0 . 2 2} \\
(3.03)\end{array}$ & $\begin{array}{c}\mathbf{0 . 4 4} \\
(3.68)\end{array}$ & $\begin{array}{c}\mathbf{0 . 3 7} \\
(3.15)\end{array}$ \\
\hline Twins (3 turn 5) & $\begin{array}{c}0.03 \\
(0.61)\end{array}$ & $\begin{array}{c}0.05 \\
(1.17)\end{array}$ & $\begin{array}{c}0.09 \\
(1.19)\end{array}$ & $\begin{array}{c}0.12 \\
(1.67)\end{array}$ & $\begin{array}{c}0.05 \\
(0.41)\end{array}$ & $\begin{array}{c}0.02 \\
(0.18)\end{array}$ \\
\hline $00-01$ & & $\begin{array}{c}0.01 \\
(0.68) \\
\end{array}$ & & & & \\
\hline 01-02 & & $\begin{array}{c}-0.02 \\
(-1.00)\end{array}$ & & & & \\
\hline $00-02$ & & & & $\begin{array}{c}-0.01 \\
(-0.59)\end{array}$ & & \\
\hline Arabs & & $\begin{array}{c}\mathbf{- 0 . 0 9} \\
(-2.57)\end{array}$ & & $\begin{array}{c}-\mathbf{- 0 . 2 2} \\
(-3.91)\end{array}$ & & $\begin{array}{c}\mathbf{- 0 . 1 8} \\
(-1.97)\end{array}$ \\
\hline Orthodox Jews & & $\begin{array}{c}\mathbf{0 . 1 4} \\
(8.54)\end{array}$ & & $\begin{array}{c}\mathbf{0 . 1 9} \\
(6.82)\end{array}$ & & $\begin{array}{c}\mathbf{0 . 1 1} \\
(2.02)\end{array}$ \\
\hline Virtual Price A & & $\begin{array}{l}\mathbf{- 0 . 0 8} \\
(-2.74)\end{array}$ & & $\begin{array}{c}-\mathbf{- 0 . 1 8} \\
(-3.25)\end{array}$ & & $\begin{array}{c}-\mathbf{0 . 2 3} \\
(-2.12)\end{array}$ \\
\hline Virtual Price C & & $\begin{array}{c}\mathbf{0 . 0 4} \\
(2.31)\end{array}$ & & $\begin{array}{c}-0.01 \\
(-0.40)\end{array}$ & & $\begin{array}{c}-0.09 \\
(-1.78)\end{array}$ \\
\hline Apartment Size & & $\begin{array}{c}0.00 \\
(0.09)\end{array}$ & & $\begin{array}{c}0.00 \\
(1.31)\end{array}$ & & $\begin{array}{c}0.00 \\
(1.68)\end{array}$ \\
\hline $\begin{array}{l}\text { Apartment Size } \\
\text { Unknown }\end{array}$ & & $\begin{array}{c}-0.06 \\
(-1.85)\end{array}$ & & $\begin{array}{c}0.00 \\
(0.06)\end{array}$ & & $\begin{array}{c}-0.01 \\
(-0.12)\end{array}$ \\
\hline Poverty Indicator & & $\begin{array}{c}0.04 \\
(0.63) \\
\end{array}$ & & $\begin{array}{c}0.04 \\
(0.33) \\
\end{array}$ & & $\begin{array}{c}0.05 \\
(0.33) \\
\end{array}$ \\
\hline Garden Owners & & $\begin{array}{c}0.02 \\
(0.48)\end{array}$ & & $\begin{array}{c}-0.03 \\
(-0.42)\end{array}$ & & $\begin{array}{c}0.06 \\
(0.49)\end{array}$ \\
\hline Garden Size & & $\begin{array}{c}0.00 \\
(0.81)\end{array}$ & & $\begin{array}{c}0.00 \\
(0.87)\end{array}$ & & $\begin{array}{c}-0.00 \\
(-0.28)\end{array}$ \\
\hline $\begin{array}{l}\text { Number of } \\
\text { observations }\end{array}$ & 2,832 & 2,832 & 1,469 & 1,469 & 457 & 457 \\
\hline
\end{tabular}

t statistics are in parenthesis. 
Table 7: Logit Estimation results

\begin{tabular}{|c|c|c|c|c|c|c|}
\hline \multirow[b]{2}{*}{ Intercept } & \multicolumn{2}{|c|}{ After One Year } & \multicolumn{2}{|c|}{ After Two Years } & \multicolumn{2}{|c|}{ After Three Years } \\
\hline & $\begin{array}{c}\mathbf{- 1 . 3 8} \\
(810.53) \\
\end{array}$ & $\begin{array}{c}\mathbf{- 1 . 6 6} \\
(53.25) \\
\end{array}$ & $\begin{array}{c}\mathbf{- 0 . 3 4} \\
(40.38) \\
\end{array}$ & $\begin{array}{c}\mathbf{- 0 . 4 6} \\
(1.28) \\
\end{array}$ & $\begin{array}{c}\mathbf{- 0 . 1 9} \\
(3.98) \\
\end{array}$ & $\begin{array}{l}-0.46 \\
(1.28)\end{array}$ \\
\hline Twins (4 turn 6) & $\begin{array}{c}0.49 \\
(3.75)\end{array}$ & $\begin{array}{c}0.40 \\
(2.38)\end{array}$ & $\begin{array}{c}\mathbf{1 . 0 1} \\
(9.74)\end{array}$ & $\begin{array}{c}1.02 \\
(9.14)\end{array}$ & $\begin{array}{c}2.27 \\
(9.04)\end{array}$ & $\begin{array}{c}2.05 \\
(7.15)\end{array}$ \\
\hline Twins (3 turn 5) & $\begin{array}{c}0.15 \\
(0.37)\end{array}$ & $\begin{array}{c}0.31 \\
(1.46)\end{array}$ & $\begin{array}{c}0.35 \\
(1.40)\end{array}$ & $\begin{array}{c}0.47 \\
(2.39)\end{array}$ & $\begin{array}{c}0.19 \\
(0.16)\end{array}$ & $\begin{array}{c}0.09 \\
(0.03)\end{array}$ \\
\hline $00-01$ & & $\begin{array}{c}0.09 \\
(0.55) \\
\end{array}$ & & & & \\
\hline 01-02 & & $\begin{array}{l}-0.11 \\
(0.92)\end{array}$ & & & & \\
\hline $00-02$ & & & & $\begin{array}{l}-0.06 \\
(0.25)\end{array}$ & & \\
\hline Arabs & & $\begin{array}{l}\mathbf{- 1 . 0 6} \\
(9.08)\end{array}$ & & $\begin{array}{c}\mathbf{- 1 . 3 5} \\
(14.86)\end{array}$ & & $\begin{array}{l}\mathbf{- 0 . 9 6} \\
(3.95)\end{array}$ \\
\hline Orthodox Jews & & $\begin{array}{c}\mathbf{0 . 8 3} \\
(67.20)\end{array}$ & & $\begin{array}{c}\mathbf{0 . 7 7} \\
(42.07)\end{array}$ & & $\begin{array}{c}\mathbf{0 . 4 9} \\
(4.04)\end{array}$ \\
\hline Virtual Price A & & $\begin{array}{l}\mathbf{- 0 . 7 0} \\
(8.51)\end{array}$ & & $\begin{array}{c}\mathbf{0 . 7 5} \\
(10.97)\end{array}$ & & $\begin{array}{l}-1.15 \\
(4.30)\end{array}$ \\
\hline Virtual Price C & & $\begin{array}{c}\mathbf{0 . 2 4} \\
(5.62)\end{array}$ & & $\begin{array}{c}\mathbf{0 . 6 0} \\
(6.67)\end{array}$ & & $\begin{array}{l}\mathbf{- 0 . 3 9} \\
(3.17)\end{array}$ \\
\hline Apartment Size & & $\begin{array}{c}0.00 \\
(0.00)\end{array}$ & & $\begin{array}{c}0.00 \\
(1.52)\end{array}$ & & $\begin{array}{c}0.01 \\
(2.58)\end{array}$ \\
\hline $\begin{array}{l}\text { Apartment Size } \\
\text { Unknown }\end{array}$ & & $\begin{array}{l}-0.48 \\
(4.37)\end{array}$ & & $\begin{array}{l}-0.03 \\
(0.01)\end{array}$ & & $\begin{array}{l}-0.11 \\
(0.06)\end{array}$ \\
\hline Poverty Indicator & & $\begin{array}{c}0.29 \\
(0.49) \\
\end{array}$ & & $\begin{array}{c}0.17 \\
(0.13) \\
\end{array}$ & & $\begin{array}{c}0.22 \\
(0.11)\end{array}$ \\
\hline Garden Owners & & $\begin{array}{c}0.11 \\
(0.20)\end{array}$ & & $\begin{array}{l}-0.13 \\
(0.18)\end{array}$ & & $\begin{array}{c}0.23 \\
(0.20)\end{array}$ \\
\hline Garden Size & & $\begin{array}{c}0.00 \\
(1.02)\end{array}$ & & $\begin{array}{c}0.00 \\
(0.87)\end{array}$ & & $\begin{array}{l}-0.00 \\
(0.05)\end{array}$ \\
\hline $\begin{array}{l}\text { Number of } \\
\text { observations }\end{array}$ & 2,832 & 2,832 & 1,469 & 1,469 & 457 & 457 \\
\hline
\end{tabular}

Wald Chi-Square statistics are in parenthesis 
Table 8: OLS Estimation results- the size of selection bias

(The cross section population is composed of households who have 5 or 6 members. The omitted variable is five-member household.)

\begin{tabular}{|c|c|c|c|c|}
\hline \multirow[b]{2}{*}{ Intercept } & \multicolumn{2}{|c|}{$\begin{array}{c}\text { Our experiment } \\
3 \text { year after expansion }\end{array}$} & \multicolumn{2}{|c|}{$\begin{array}{c}\text { Cross section } \\
\text { (2002) }\end{array}$} \\
\hline & $\begin{array}{c}\mathbf{0 . 4 5} \\
(18.77)\end{array}$ & $\begin{array}{c}\mathbf{0 . 3 9} \\
(4.18)\end{array}$ & $\begin{array}{c}\mathbf{0 . 6 0} \\
(137.88)\end{array}$ & $\begin{array}{c}\mathbf{0 . 3 3} \\
(33.13) \\
\end{array}$ \\
\hline 6 members & & & $\begin{array}{c}\mathbf{0 . 0 5} \\
(7.07)\end{array}$ & $\begin{array}{c}\mathbf{0 . 0 3} \\
(2.30)\end{array}$ \\
\hline Twins & $\begin{array}{c}\mathbf{0 . 4 4} \\
(3.68)\end{array}$ & $\mathbf{0 . 3 7}(3.15)$ & & \\
\hline Arabs & & $\begin{array}{c}\mathbf{- 0 . 1 8} \\
(-1.97)\end{array}$ & & $\begin{array}{c}\mathbf{- 0 . 0 6} \\
(-5.30) \\
\end{array}$ \\
\hline Orthodox Jews & & $\begin{array}{c}\mathbf{0 . 1 1} \\
(2.02)\end{array}$ & & $\begin{array}{c}\mathbf{0 . 0 9} \\
(11.77) \\
\end{array}$ \\
\hline Virtual Price A & & $\begin{array}{c}-\mathbf{- 0 . 2 3} \\
(-2.12)\end{array}$ & & $\begin{array}{c}-\mathbf{0 . 2 2} \\
(-14.23) \\
\end{array}$ \\
\hline Virtual Price C & & $\begin{array}{c}-0.09 \\
(-1.78)\end{array}$ & & $\begin{array}{c}\mathbf{0 . 2 2} \\
(26.40)\end{array}$ \\
\hline Apartment Size & & $\begin{array}{c}0.00 \\
(1.68)\end{array}$ & & $\begin{array}{c}0.00 \\
(1.21)\end{array}$ \\
\hline $\begin{array}{l}\text { Apartment Size } \\
\text { Unknown }\end{array}$ & & $\begin{array}{c}-0.01 \\
(-0.12)\end{array}$ & & $\begin{array}{c}0.00 \\
(0.29)\end{array}$ \\
\hline Poverty Indicator & & $\begin{array}{c}0.05 \\
(0.33) \\
\end{array}$ & & $\begin{array}{c}-0.01 \\
(-0.69) \\
\end{array}$ \\
\hline Garden Owners & & $\begin{array}{c}0.06 \\
(0.49)\end{array}$ & & $\begin{array}{c}\mathbf{0 . 1 1} \\
(9.08)\end{array}$ \\
\hline Garden Size & & $\begin{array}{c}-0.00 \\
(-0.28)\end{array}$ & & $\begin{array}{c}-\mathbf{- 0 . 0 0} \\
(-2.61)\end{array}$ \\
\hline $\begin{array}{l}\text { Number of } \\
\text { observations }\end{array}$ & 457 & 457 & 20,541 & 20,541 \\
\hline
\end{tabular}

$\mathrm{t}$ statistics are in parenthesis 


\section{References}

Anderson Patricia and Meyer Bruce (1997), “Unemployment Insurance Takeup Rates and the After-Tax Value of Benefits”, Quarterly Journal of Economics, August 1997, 913-937.

Ashenfelter Orley (1983), "Determining Participation in Income-Tested Social Programs”, Journal of the American Statistical Association, 78, 383.

Ashenfelter Orley and Alan Krueger, (1994) "Estimates of the Economic Return to Schooling from A New Sample of Twins" American Economic Review 84 (5), pp. 1157-1173.

Angrist Joshua (2001) "Estimations of Limited Dependent Variable Models with Dummy Endogenous Regressors: Simple Strategies for Empirical Practice,” Journal of Business and Economic Statistics, 19(1):2-16.

Bertrand Marianne, Luttmer Erzo and Mullainathan Sendhil (2000), "Network Effects and Welfare Cultures,” Quarterly Journal of Economics, August 2000, 1019-1056.

Bitler Marianne, Currie Janet and Scholz John (2003), "WIC Eligibility and Participation,” Journal of Human Resources, 38(4) Supplement, 1139-1179.

Blank Rebecca and Card David (1991), "Recent Trends in Insured and Uninsured Unemployment: Is There an Explanation?” Quarterly Journal of Economics, November 1991.

Blank Rebecca and Ruggles Patricia (1996), "Whan Do Women Use AFDC \& Food Stamps? The Dynamics of Eligibility vs. Participation”, The Journal of Human Resources, 31(1) 57-89.

Borjas George and Hilton Lynette (1996), “Immigration and the Welfare State: Immigrant Participation in Means-Tested Entitlement Programs,” Quarterly Journal of Economics, May 1996. 
Currie Janet (2004) “The Take Up of Social Benefits.” IZA DP No. 1103.

Currie Janet (2000), "Do Children of Immigrants Make Differential Use of Public Health Insurance?, "Issues in Economics of Immigration, George Borjas (ed.) University of Chicago Press.

Dahan Momi and Nisan Udi, (2007) “The Unintended Consequences of IBT Pricing Policy in Urban Water. “ Forthcoming in Water Resources Research. This paper is available at http://ssrn.com/abstract=760824.

Momi Dahan and Udi Nisan, "Low Take-up Rates: The Role of Information", CESifo Working Paper No. 1829, October 2006.

http://www.cesifo-group.de/

Daponte Beth Osborne, Sanders Seth, Taylor Lowell (1999), "Why Do Low Income Households Not Use Food Stamps? Evidence from an Experiment,” Journal of Human Resources, vol. 34(3), 612-628.

Duflo Esther and Saez Emmanuel (2003), “The Role of Information and Social Interactions in Retirement Plan Decisions: Evidence From a Randomized Experiment” Quarterly Journal of Economics, August 2003.

Hernanz V., Malherbet F. and Pellizzari M. (2004), “Take-up of Welfare Benefits in OECD Countries: A Review of the Evidence” OECD Social, Employment and Migration Working Papers No. 17 OECD Publishing.

McGarry Kathleen (1996), "Factors Determining Participation of the Elderly in Supplemental Security Income,” Journal of Human Resources, 31(2), 331-358.

Moffitt Robert (1983), “An Economic Model of Welfare Stigma,” American Economic Review, 73, 1023-1035.

OECD (1999), The Price of Water: Trends in OECD Countries. 
Rosenzweig R. Mark and Wolpin I. Kenneth, (1980) "Testing the Quantity-Quality Fertility Model: The Use of Twins as a Natural Experiment," Econometrica, Vol. 48, No. 1, January, pp. 227-240

Rosenzweig R. Mark and Wolpin I. Kenneth, (1980) "Life-Cycle Labor Supply and Fertility: Causal Inferences from Household Models," Journal of Political Economy, Vol. 88, No. 2, April, pp. 328-348. 


\section{Appendix 1: Application Form}

“Hagihon” - Jerusalem Water Company

\section{Declaration - Number of household members*}

First Name Surname

I.D. Number

I declare that residing in my apartment, located on Street, number

there are members. (Less than age 18)

For children under age 18, please complete the following:

Name I.D.

Name I.D.

Name I.D.

Name I.D.

Total number of persons residing in the apartment:

Below is my signature. I confirm that all details are true, and will provide notification of any changes in these details.

Signature Date

*Translated to English by the authors 


\section{CESifo Working Paper Series}

(for full list see www.cesifo-group.de)

1824 J. Atsu Amegashie, A Psychological Game with Interdependent Preference Types, October 2006

1825 Kurt R. Brekke, Ingrid Koenigbauer and Odd Rune Straume, Reference Pricing of Pharmaceuticals, October 2006

1826 Sean Holly, M. Hashem Pesaran and Takashi Yamagata, A Spatio-Temporal Model of House Prices in the US, October 2006

1827 Margarita Katsimi and Thomas Moutos, Inequality and the US Import Demand Function, October 2006

1828 Eytan Sheshinski, Longevity and Aggregate Savings, October 2006

1829 Momi Dahan and Udi Nisan, Low Take-up Rates: The Role of Information, October 2006

1830 Dieter Urban, Multilateral Investment Agreement in a Political Equilibrium, October 2006

1831 Jan Bouckaert and Hans Degryse, Opt In Versus Opt Out: A Free-Entry Analysis of Privacy Policies, October 2006

1832 Wolfram F. Richter, Taxing Human Capital Efficiently: The Double Dividend of Taxing Non-qualified Labour more Heavily than Qualified Labour, October 2006

1833 Alberto Chong and Mark Gradstein, Who's Afraid of Foreign Aid? The Donors' Perspective, October 2006

1834 Dirk Schindler, Optimal Income Taxation with a Risky Asset - The Triple Income Tax, October 2006

1835 Andy Snell and Jonathan P. Thomas, Labour Contracts, Equal Treatment and WageUnemployment Dynamics, October 2006

1836 Peter Backé and Cezary Wójcik, Catching-up and Credit Booms in Central and Eastern European EU Member States and Acceding Countries: An Interpretation within the New Neoclassical Synthesis Framework, October 2006

1837 Lars P. Feld, Justina A.V. Fischer and Gebhard Kirchgaessner, The Effect of Direct Democracy on Income Redistribution: Evidence for Switzerland, October 2006

1838 Michael Rauscher, Voluntary Emission Reductions, Social Rewards, and Environmental Policy, November 2006 
1839 Vincent Vicard, Trade, Conflicts, and Political Integration: the Regional Interplays, November 2006

1840 Erkki Koskela and Mikko Puhakka, Stability and Dynamics in an Overlapping Generations Economy under Flexible Wage Negotiation and Capital Accumulation, November 2006

1841 Thiess Buettner, Michael Overesch, Ulrich Schreiber and Georg Wamser, Taxation and Capital Structure Choice - Evidence from a Panel of German Multinationals, November 2006

1842 Guglielmo Maria Caporale and Alexandros Kontonikas, The Euro and Inflation Uncertainty in the European Monetary Union, November 2006

1843 Jan K. Brueckner and Ann G. Largey, Social Interaction and Urban Sprawl, November 2006

1844 Eytan Sheshinski, Differentiated Annuities in a Pooling Equilibrium, November 2006

1845 Marc Suhrcke and Dieter Urban, Are Cardiovascular Diseases Bad for Economic Growth?, November 2006

1846 Sam Bucovetsky and Andreas Haufler, Preferential Tax Regimes with Asymmetric Countries, November 2006

1847 Luca Anderlini, Leonardo Felli and Andrew Postlewaite, Should Courts always Enforce what Contracting Parties Write?, November 2006

1848 Katharina Sailer, Searching the eBay Marketplace, November 2006

1849 Paul De Grauwe and Pablo Rovira Kaltwasser, A Behavioral Finance Model of the Exchange Rate with Many Forecasting Rules, November 2006

1850 Doina Maria Radulescu and Michael Stimmelmayr, ACE vs. CBIT: Which is Better for Investment and Welfare?, November 2006

1851 Guglielmo Maria Caporale and Mario Cerrato, Black Market and Official Exchange Rates: Long-Run Equilibrium and Short-Run Dynamics, November 2006

1852 Luca Anderlini, Leonardo Felli and Andrew Postlewaite, Active Courts and Menu Contracts, November 2006

1853 Andreas Haufler, Alexander Klemm and Guttorm Schjelderup, Economic Integration and Redistributive Taxation: A Simple Model with Ambiguous Results, November 2006

1854 S. Brock Blomberg, Thomas DeLeire and Gregory D. Hess, The (After) Life-Cycle Theory of Religious Contributions, November 2006 
1855 Albert Solé-Ollé and Pilar Sorribas-Navarro, The Effects of Partisan Alignment on the Allocation of Intergovernmental Transfers. Differences-in-Differences Estimates for Spain, November 2006

1856 Biswa N. Bhattacharyay, Understanding the Latest Wave and Future Shape of Regional Trade and Cooperation Agreements in Asia, November 2006

1857 Matz Dahlberg, Eva Mörk, Jørn Rattsø and Hanna Ågren, Using a Discontinuous Grant to Identify the Effect of Grants on Local Taxes and Spending, November 2006

1858 Ernesto Crivelli and Klaas Staal, Size and Soft Budget Constraints, November 2006

1859 Jens Brøchner, Jesper Jensen, Patrik Svensson and Peter Birch Sørensen, The Dilemmas of Tax Coordination in the Enlarged European Union, November 2006

1860 Marcel Gérard, Reforming the Taxation of Multijurisdictional Enterprises in Europe, "Coopetition" in a Bottom-up Federation, November 2006

1861 Frank Blasch and Alfons J. Weichenrieder, When Taxation Changes the Course of the Year - Fiscal Year Adjustments and the German Tax Reform 2000/2001, November 2006

1862 Hans Jarle Kind, Tore Nilssen and Lars Sørgard, Competition for Viewers and Advertisers in a TV Oligopoly, November 2006

1863 Bart Cockx, Stéphane Robin and Christian Goebel, Income Support Policies for PartTime Workers: A Stepping-Stone to Regular Jobs? An Application to Young LongTerm Unemployed Women in Belgium, December 2006

1864 Sascha O. Becker and Marc-Andreas Muendler, The Effect of FDI on Job Separation, December 2006

1865 Christos Kotsogiannis and Robert Schwager, Fiscal Equalization and Yardstick Competition, December 2006

1866 Mikael Carlsson, Stefan Eriksson and Nils Gottfries, Testing Theories of Job Creation: Does Supply Create Its Own Demand?, December 2006

1867 Jacques H. Drèze, Charles Figuières and Jean Hindriks, Voluntary Matching Grants Can Forestall Social Dumping, December 2006

1868 Thomas Eichner and Marco Runkel, Corporate Income Taxation of Multinationals and Unemployment, December 2006

1869 Balázs Égert, Central Bank Interventions, Communication and Interest Rate Policy in Emerging European Economies, December 2006

1870 John Geweke, Joel Horowitz and M. Hashem Pesaran, Econometrics: A Bird's Eye View, December 2006 
1871 Hans Jarle Kind, Marko Koethenbuerger and Guttorm Schjelderup, Taxation in TwoSided Markets, December 2006

1872 Hans Gersbach and Bernhard Pachl, Cake Division by Majority Decision, December 2006

1873 Gunther Schnabl, The Evolution of the East Asian Currency Baskets - Still Undisclosed and Changing, December 2006

1874 Horst Raff and Michael J. Ryan, Firm-Specific Characteristics and the Timing of Foreign Direct Investment Projects, December 2006

1875 Jukka Pirttilä and Håkan Selin, How Successful is the Dual Income Tax? Evidence from the Finnish Tax Reform of 1993, December 2006

1876 Agnieszka Stążka, Sources of Real Exchange Rate Fluctuations in Central and Eastern Europe - Temporary or Permanent?, December 2006

1877 Xavier Calsamiglia, Teresa Garcia-Milà and Therese J. McGuire, Why do Differences in the Degree of Fiscal Decentralization Endure?, December 2006

1878 Natacha Gilson, How to be Well Shod to Absorb Shocks? Shock Synchronization and Joining the Euro Zone, December 2006

1879 Scott Alan Carson, Modern Health Standards for Peoples of the Past: Biological Conditions by Race in the American South, 1873 - 1919, December 2006

1880 Peter Huber, Michael Pfaffermayr and Yvonne Wolfmayr, Are there Border Effects in the EU Wage Function?, December 2006

1881 Harry Flam and Håkan Nordström, Euro Effects on the Intensive and Extensive Margins of Trade, December 2006

1882 Panu Poutvaara and Mikael Priks, Hooliganism in the Shadow of the 9/11 Terrorist Attack and the Tsunami: Do Police Reduce Group Violence?, December 2006

1883 Ruud A. de Mooij and Gaëtan Nicodème, Corporate Tax Policy, Entrepreneurship and Incorporation in the EU, December 2006

1884 Johannes Becker and Clemens Fuest, Corporate Tax Policy and International Mergers and Acquisitions - Is the Tax Exemption System Superior?, January 2007

1885 Momi Dahan and Udi Nisan, The Effect of Benefits Level on Take-up Rates: Evidence from a Natural Experiment, January 2007 